Research Paper

\title{
Stat3-positive tumor cells contribute to vessels neoformation in primary central nervous system lymphoma
}

\author{
Simona Ruggieri ${ }^{1}$, Roberto Tamma ${ }^{1,5}$, Nicoletta Resta ${ }^{2}$, Francesco Albano ${ }^{3}$, \\ Nicoletta Coccaro ${ }^{3}$, Daria Loconte ${ }^{2}$, Tiziana Annese ${ }^{1}$, Mariella Errede ${ }^{1}$, Giorgina \\ Specchia ${ }^{3}$, Rebecca Senetta ${ }^{4}$, Paola Cassoni ${ }^{4}$, Domenico Ribatti ${ }^{1,5}$, Beatrice Nico ${ }^{1}$ \\ ${ }^{1}$ Department of Basic Medical Sciences, Neurosciences and Sensory Organs, Section of Human Anatomy and Histology, \\ University of Bari Medical School, Bari, Italy \\ ${ }^{2}$ Division of Medical Genetics, Department of Biomedical Sciences and Human Oncology (DIMO), University of Bari Medical \\ School, Bari, Italy \\ ${ }^{3}$ Department of Emergency and Transplantation, Section of Hematology, University of Bari Medical School, Bari, Italy \\ ${ }^{4}$ Department of Biomedical Sciences and Human Oncology, University of Turin Medical School, Turin, Italy \\ ${ }^{5}$ National Cancer Institute "Giovanni Paolo II", Bari, Italy \\ Correspondence to: Beatrice Nico, email: beatrice.nico@uniba.it \\ Domenico Ribatti, email: domenico.ribatti@uniba.it
}

Keywords: angiogenesis, cancer stem cells, endothelium, lymphoma, Stat3

Received: January 12, 2017

Accepted: March 01, 2017

Published: March 10, 2017

Copyright: Ruggieri et al. This is an open-access article distributed under the terms of the Creative Commons Attribution License (CC-BY), which permits unrestricted use, distribution, and reproduction in any medium, provided the original author and source are credited.

\section{ABSTRACT}

With the aim of elucidating the relationship between Stat3 expression and tumor vessels abnormalities in the PCNLs, in this study we evaluated Stat3 and pStat3 expression by Real-time PCR and by immunohistochemistry in biopsy sections from PCNSL patients. Correlations of the expression levels with the presence of aberrant vessels were analyzed by confocal laser microscopy analysis, using FVIII as endothelial cell marker, CD133 and nestin as cancer stem cell (CSC) marker, CD20 as tumor cell marker, and Stat3. In addition, we investigated Stat3 mutations in lymphoma cells to clarify the role of the constitutive expression of Stat3 and of its phosphorylated forms. Results showed that in PCNSL, putative endothelial cells lining the vessels are heterogeneous, expressing FVIII/ pStat3/CD133 (presumably originally they are vascular progenitor cells), as well as FVIII/CD20/CD133 (presumably originally they are tumor cells). Finally, we detected a fraction of the FVIII $^{+}$endothelial cell that co-expressed Stat3 bearing a tetraploid karyotype, while no amplification signal for the Stat3 gene was detected.

\section{INTRODUCTION}

Primary Central Nervous System Lymphoma (PCNSL) has an aggressive course and poor prognosis, with a median survival of less than 20-24 months $[1,2]$. PCNSL accounts for $1-3 \%$ of all primary brain tumors [3], but its incidence has increased in recent decades. The majority of PCNSL are diffuse large B-cell Lymphomas [4] and lymphomatous cells are typically localized in the perivascular areas [3].

Angiogenesis has a prognostic value in human NHLs [5], and PCNSL [6]. Expression of vascular endothelial growth factor (VEGF) in PCNSL cells is correlated with microvascular density, with longer survival and blood-brain barrier alterations [6]. We have previously demonstrated that different type of cells are involved in the formation of vascular wall in PCNSL [7]. Cancerlike stem cells (CSCs) may be involved in formation of tumor vessels, including brain tumors, through a cross-talk between endothelial cells and CSCs [8-10].

The signal transducer and activator of transcription 3 (Stat3) is involved in angiogenesis [11]. Janus kinase (JAK) phosphorylates Stat proteins, and active Stat 3 contributes to the malignant phenotype [12]. Activated Stat3 promotes tumor cell proliferation and survival, immune suppression, invasion, and angiogenesis [13]. A higher Stat 3 activation in tumor cells is associated with lower survival rates of patients with several malignant tumors [14-17]. High levels of phosphorylated Stat3 (pStat3) protein were found in diffuse large B-cell lymphoma 
$[18,19]$, while data on the expression of Stat3 in PCNSL are controversial [20-22]. Moreover, Stat3 favors proliferation and maintenance of CSCs, and its inhibition blocks tumor formation in glioblastoma [23].

With the aim of elucidating the relationship between Stat 3 expression and tumor vessels abnormalities in the PCNSL, we evaluated Stat 3 and pStat 3 expression by Real-time PCR and by immunohistochemistry in biopsy sections from PCNSL patients. Correlations of the expression levels with the presence of aberrant vessels were analyzed by confocal laser microscopy analysis, using FVIII as endothelial cell marker, CD133 and nestin as CSC marker, CD20 as tumor cell marker, and Stat3. In addition, we investigated Stat 3 mutations in lymphoma cells to clarify the role of the constitutive expression of Stat 3 and of its phosphorylated forms.

\section{RESULTS}

\section{Endothelial and tumor cells express Stat3}

Stat3 immunohistochemical expression showed high levels of total and phosphorylated Stat3 protein in tumor brain compared to normal brain. Stat 3 showed an intense staining in tumor tissues (Figure 1A) compared to normal brain lacking Stat3 labeling (Figure 1C).Tumor vessels were lined by $\mathrm{Stat}^{+}$cells and tumor cells were identified near to the vessel wall (Figure 1B). After Real-time PCR (Figure 1D) a significant difference in Stat3 expression between tumor and control brain tissues was observed. To better identify changes in the expression of phosphorylated and total form of Stat3, immunohistochemical reactions were performed in the same areas of tumor tissue. Stat3 displayed a higher expression (Figure 2A) compared to pStat3, which strongly labeled the nuclei of the endothelial cells and clusters of tumor perivascular cells in the same area (Figure 2B). pStat 3 was not detected in the control brain tissue (Figure 2C). Morphometric analysis showed an increased expression of Stat 3 and pStat 3 in the tumor brain tissues compared with control tissues (Figure 2D). After dual confocal immunofluorescence reactions, tumor vessels appeared lined by endothelial cells expressing both FVIII and Stat3 signals (Figure 3A-3C) while in the control brain tissue only $\mathrm{FVIII}^{+}$vessels were detectable (Figure 3D).

\section{Endothelial tumor cells express CD133 and nestin stem cells marker}

After immunohistochemistry, tumor vessels appeared lined by $\mathrm{CD}_{133}{ }^{+}$(Figure 4A, 4B) and nestin ${ }^{+}$(Figure 4D, $4 \mathrm{E})$ cells and $\mathrm{CD}_{133^{+}}$and nestin ${ }^{+}$tumor cells were detected near the vessels (Figure 4B, 4E). Instead, in the control

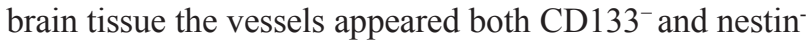
(Figure 4C, 4F). After dual confocal immunofluorescence reactions, tumor vessels were lined by both $\mathrm{CD}_{133^{+}} \mathrm{CSCs}$ and $\mathrm{FVIII}^{+}$endothelial cells (Figure 4H-4L), as well as nestin ${ }^{+} \mathrm{CSC}$ and $\mathrm{FVIII}^{+}$(Figure 4N-4P) cells, with merged colocalization fluorescence signals. Moreover we identified CD133 ${ }^{+}$FVIII $^{-}$vessels (Figure 4G) and nestin ${ }^{+} /$ FVIII $^{-}$vessels (Figure 4M). The morphometric analysis showed that $14 \% \pm 3$ of vessels were $\mathrm{CD} 133^{+} / \mathrm{FVIII}^{-}$and $86 \% \pm 4$ of vessels were $\mathrm{CD}_{133}{ }^{+} / \mathrm{FVIII}^{+}$, while $10 \% \pm 2$ of vessels were nestin ${ }^{+} / \mathrm{FVIII}^{-}$and $90 \% \pm 4$ were nestin ${ }^{+}$/ FVIII'.

\section{CD133-positive stem cells and CD20-positive tumor cells express pStat 3 and endothelial FVIII marker}

After dual confocal immunofluorescence reactions, pStat3 was expressed by $\mathrm{CD}_{133^{+}}$cells in the tumor tissue, showing an orange colocalization signal in the cytoplasm (Figure 5A-5C). The morphometric analysis showed that the pStat3 and CD133 labeled cells were significantly larger than unlabeled ones $(11,8 \pm 1,8$ vs $6,2 \mu \mathrm{m}$ diameter, $p<0.0001)$. Moreover, $\mathrm{pStat} 3$ and CD133 were colocalized in the tumor vessels, pStat 3 showing both cytoplasmic and nuclear expression (Figure 5D, 5E). After confocal analysis, CD20 ${ }^{+}$tumor cells appeared also $\mathrm{pStat}^{+}$(Figure 5G-5I) and vessels labeled by $\mathrm{FVIII}^{+}$ and $\mathrm{CD} 20^{+}$cells were also detected (Figure $5 \mathrm{~L}-5 \mathrm{~N}$ ). The multiple confocal immunofluorescence, confirmed the presence of tumor vessels lined by $\mathrm{FVIII}^{+}$endothelial cells (Figure 6A-6C red signal) and expressing both pStat3 (Figure 6A, 6B, 6D green signal) and CD133 (Figure 6A, 6C, 6D blue signal).

Finally, after multiple immunofluorescence labeling, tumoral vessels co-expressing FVIII endothelial marker (Figure 7A, 7B, 7C red signal ), CD20 tumoral marker (Figure 7A, 7B, 7D, green signal) and CD133 CSCs marker (Figure 7A, 7C, 7D blue signal) were recognized.

Overall, these data show, for the first time, that tumoral $\mathrm{FVIII}^{+}$vessel in PCNSL are formed by $\mathrm{CD} 20^{+} /$ $\mathrm{CD} 133^{+}$cells (Figure 7) as well as that $\mathrm{FVIII}^{+}$cells express both CD133 and pStat3 (Figure 6). Moreover, morphometric analysis shows a significant increased expression of Stat3, CD133, nestin and CD20 protein in PCNSL compared with control brain (Figure 8).

\section{Genetic analysis of Stat3 in PCNSL}

To better understand the overexpression of Stat 3 in the vessel wall and tissues of PCNSL specimens, genetic analysis of the Stat3 gene was performed. Interphase FISH analysis and the FICTION technique on the FFPE tumor samples, and Stat3 gene sequencing on genomic DNA, were carried out. The FICTION technique detected red and green aberrant fluorescent spots in the nuclei of $\mathrm{CD} 20^{+}$cells (Figure 9A). In detail, the Interphase FISH analysis, showed four red (Chr:17q21.2, Stat3) and four green (Chr:9q34.11) fluorescent spots in the nuclei of PCNSL cells, indicative 
of a tetraploid karyotype (Figure 9B). After FICTION with FVIII and Stat3 dual immunofluorescence reaction, and FISH with the Stat3 gene (red) and chromosome 9q34.11 (green) probes, tumor vessels showed a merge fluorescent colocalization signal in some vascular tracts, while in other tracts the signals were separate (Figure 9C-9D). Moreover, $\mathrm{Stat}^{+}$cells with a tetraploid karyotype were detected in the vessel wall (Figure 9E).

All Stat3 exons and adjacent intronic regions were sequenced on genomic DNA isolated from biopsy samples derived from PCNSL specimens, but no pathogenic variants were found. Only two Single Nucleotide Polymorfisms (SNPs) were detected, the Stat3 rs2293152 G-allele (minor allele count $/ \mathrm{MAF}=0.346)$ and rs3830585 dupT-allele (minor allele count/MAF $=0.402$ ).

\section{DISCUSSION}

Avascular phase followed by a vascular phase characterizes growth in both solid and haematological tumors $[25,26]$. Different mechanisms are involved in tumor angiogenesis: sprouting angiogenesis; non-sprouting angiogenesis (intussusceptive microvascular growth); postnatal vasculogenesis and vasculogenic mimicry.
Mounting evidence has shown that Stat3 is strongly linked to tumor angiogenesis and metastasis [27, 28] and is related to poor prognosis in different tumors $[15,29]$. Anti-tumor effects of Stat3 knockdown has been demonstrated by means of small interfering RNA (siRNA), micro-RNA (mi-RNA), or small molecule inhibitors [30-33]. Inhibitory molecules, which downregulate Stat 3 phosphorylation and induce apoptosis in tumor cells have been developed [34-42]. Moreover, previous studies have shown that metformin, an antidiabetic drug, could inhibit Stat3 phosphorylation and reduce risk of development in many type of cancer $[43,44]$. Therefore Stat3 is a prognostic indicator and a therapeutic target. In this study we observed pStat3 expression in tumor PCNSL vessels and cells, moreover we found high levels of total and phosphorylated Stat3 protein in tumor brain compared to normal brain. Elevated levels of the phosphorylated protein have been reported in human glioblastoma multiforme (GBM) samples [45] and in GBM cell lines [47]. IL-6 and IL-10 activate Stat proteins [47]. IL-6 contributes to tumor metastasis via the JAK/Stat3 signaling pathway [48, 49], and IL-10 phosphorylates of Stat3 in PCNSL cells [50], while the role of IL-6 in PCNSL remains poorly defined.
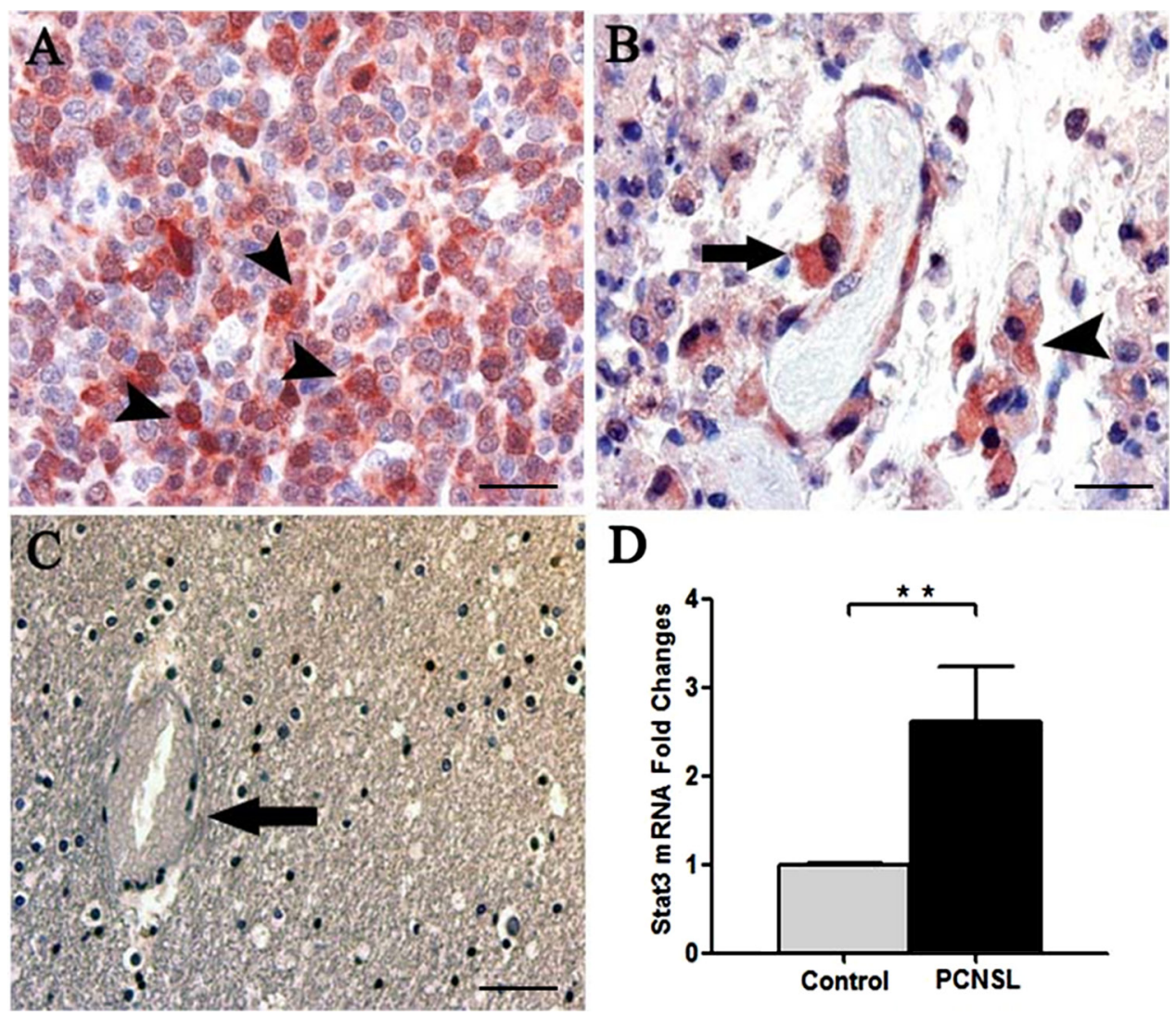

Figure 1: Stat3 Immunohistochemistry $(\mathbf{A}-\mathbf{C})$ and Stat3 messenger expression analysis (D). PCNSL section showing a strong Stat3 expression in the tumor cells (A, arrowhead) and in endothelial cells (B, arrow) lining a vessel near a cluster of Stat3 labeled tumor cells (B, arrowhead). Control brain section (C) showing a vessel (arrow) and Stat3 negative tumor cells. RT-PCR analysis (D) showing a significant Stat 3 overexpression in PCNSL $(2.623 \pm$ SEM 0.305$)$ compared to control brain $(1.00 \pm$ SEM 0.011$)(* * p<0.001$ vs Control). Scale bar: A-B $20 \mu \mathrm{m}, \mathrm{C} 40 \mu \mathrm{m}$. 


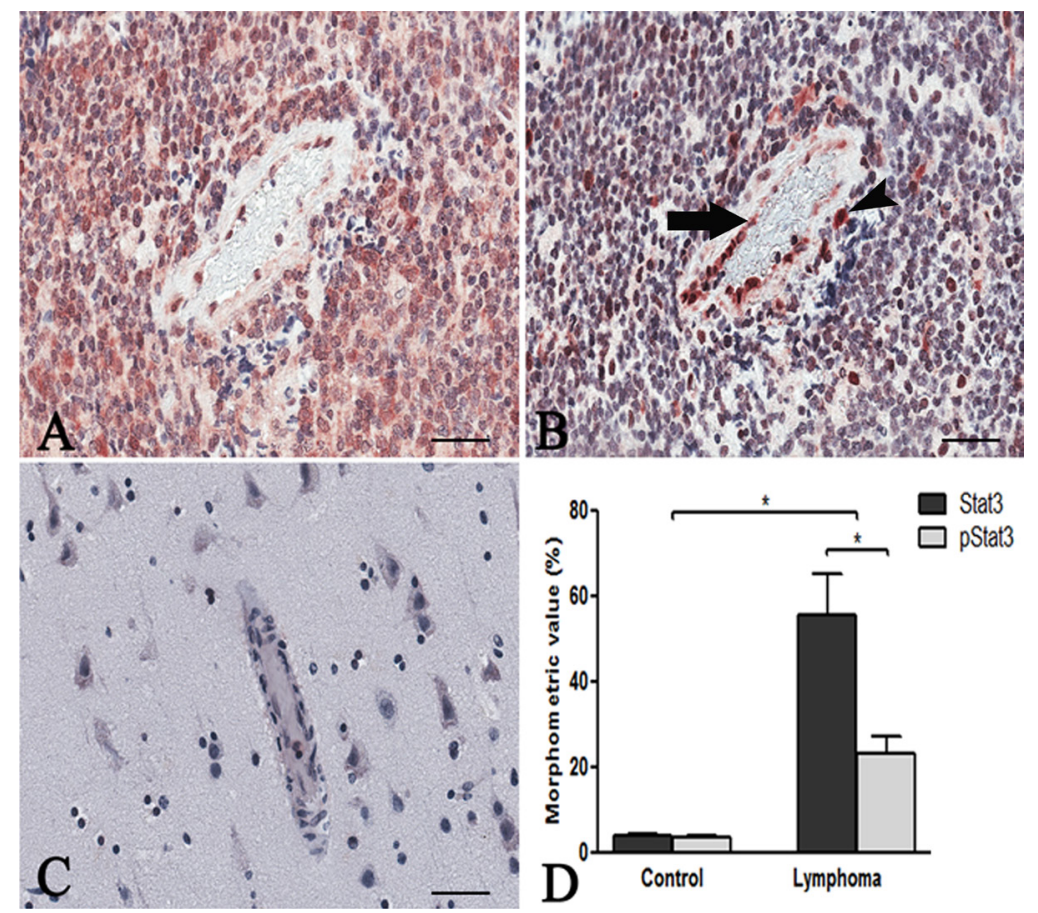

Figure 2: Stat3 and pStat3 immunohistochemistry. PCNSL serial sections showing the same area (A, B) with a higher Stat3 cytoplasmic tumor expression (A) compared to pStat3 labeling of the endothelial cells lining a vessel (B, arrow) and of tumor perivascular cells (B, arrowhead). Control brain section showing negative pStat3 expression (C). Morphometric analysis (D) reveals a significant increase of Stat3 (55.51 \pm SEM 9.414 ) and pStat3 (23.17 \pm SEM 3.88) protein in PCNSL compared to control brain $(3.7 \pm$ SEM $0.52 ; 3.6$ \pm SEM 0.10$)$ and a higher Stat 3 expression compared to pStat3. $\left({ }^{*} p<0.05\right)$ in PCNSL. Scale bar: A-C $40 \mu \mathrm{m}$.

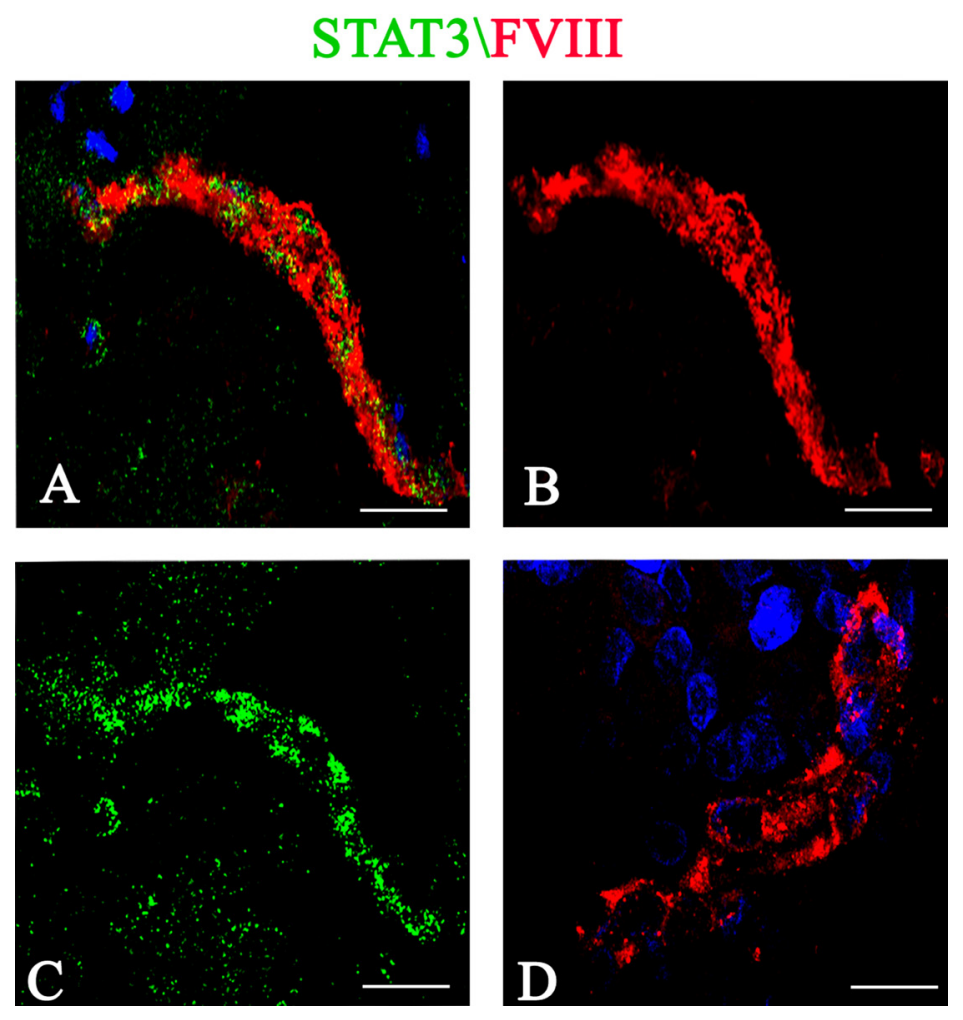

Figure 3: Stat3 (green)/FVIII (red) confocal dual immunofluorescence reaction. Tumor vessels are lined by endothelial cells expressing FVIII and Stat3 fluorescence signals (A-C). Vessels from control brain section show only the FVIII signal (D). Scale bar: A-C $20 \mu \mathrm{m} ; \mathrm{D} 12 \mu \mathrm{m}$. 
We found that pStat 3 was elevated in PCNSL brain samples compared to normal tissues. Overexpression of Stat3, as shown by Real-time PCR and immunohistochemical reactions, might mediate the cellular response to cytokines and growth factors $[51,52]$.

In this study we also demonstrated Stat 3 expression in $\mathrm{FVIII}^{+}$endothelial cells that lined PCNSL vessels and in $\mathrm{FVIII}^{+}$cluster of cells in PCNSL brain samples while in control samples endothelial cells were $\mathrm{FVIII}^{+}$. Moreover in tumor tissues, cells co-expressing pStat3 and CD133, and vessels co-expressing CD133, pStat3, CD20 and FVIII markers, were detected. Therefore, putative endothelial cells lining these vessels are heterogeneous, expressing FVIII/pStat3/CD133 (presumably originally they are
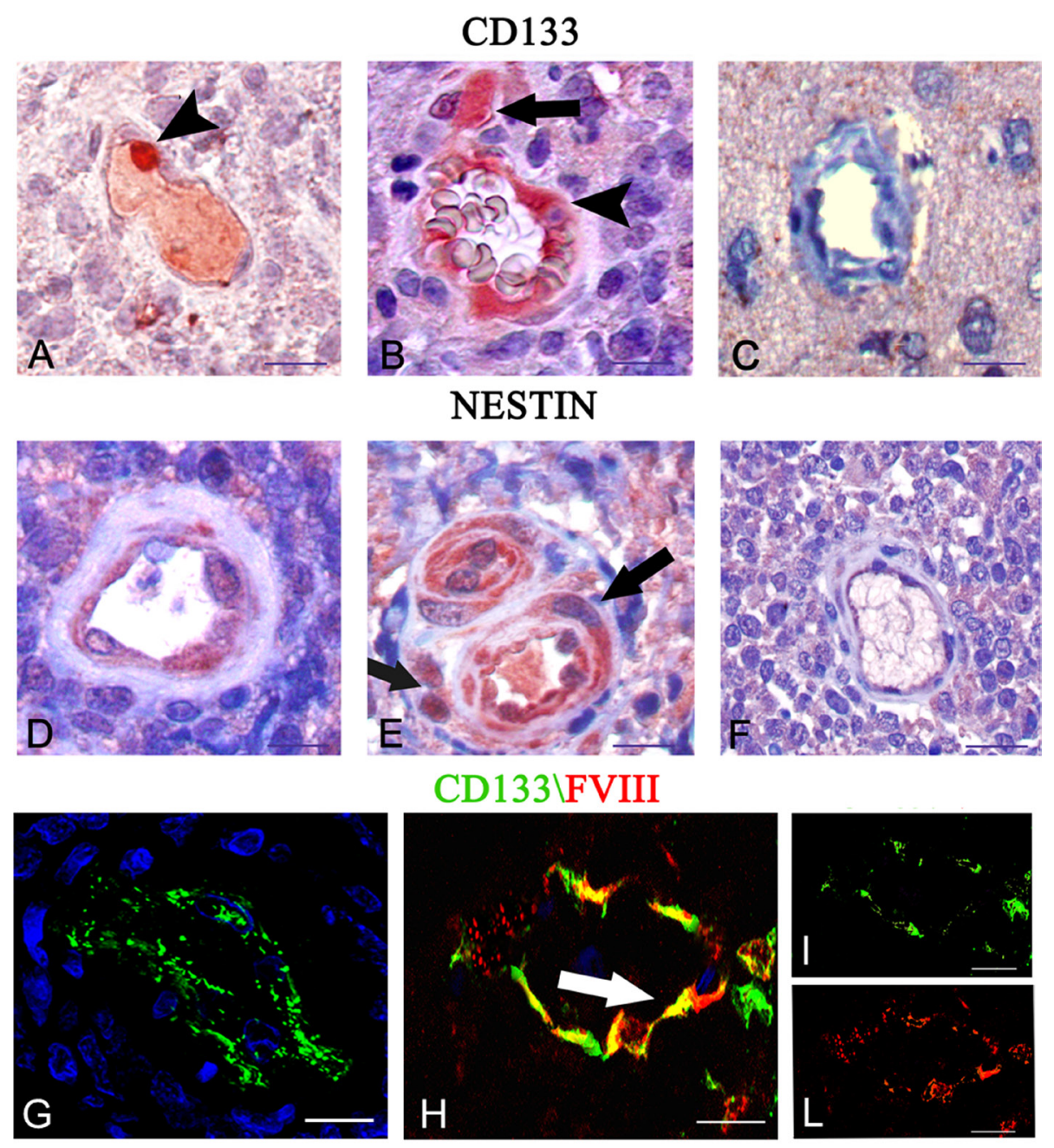

\section{CD133ไFVIII}
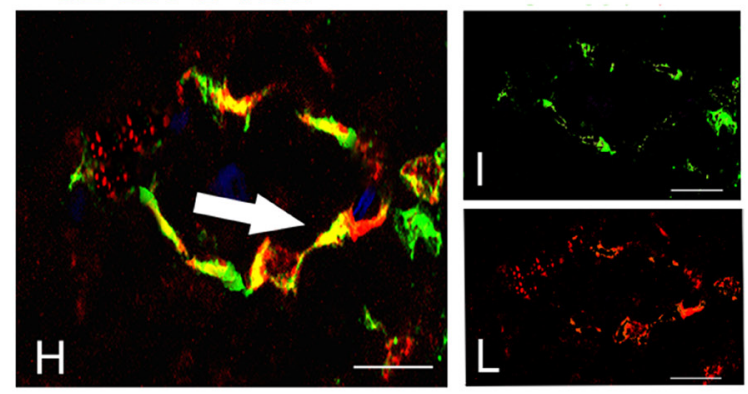

NESTINIFVIII
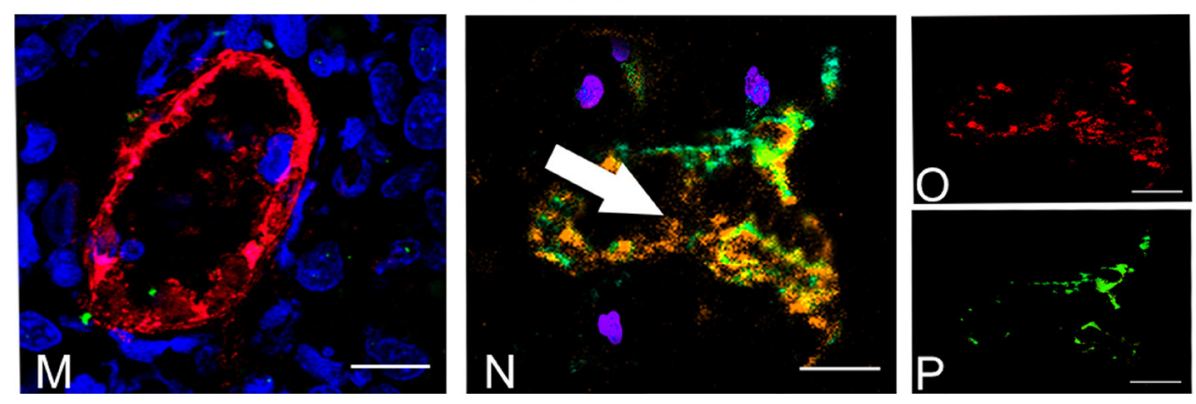

Figure 4: CD133 and nestin immunohistochemistry (A-F) and CD133 (green)/FVIII (red) (G-L), and nestin (red) /FVIII (green) (M-O) confocal dual immunofluorescence reaction. (A-E) Tumor vessels lined by CD133 (A-B arrowhead) and nestin (D-E) labeled endothelial cells near to $\mathrm{CD} 133$ (B, arrow) and nestin (E, arrow) labeled tumor cells. Control brain section showing unlabeled vessel and cells. (C, F). (G-P) Tumor endothelial cells co-expressing FVIII (H, L red) and CD133 (H, I green), and nestin (N, O red) and FVIII (N, P green) with orange colocalization signals ( H, N arrows). FVIII- tumor vessels express only CD133(G) and Nestin (M) markers. Scale bar: A-F, $10 \mu \mathrm{m} ; \mathrm{G}-\mathrm{P} 12,5 \mu \mathrm{m}$. 
vascular progenitor cells), as well as FVIII/CD20/CD133 (presumably originally they are tumor cells), as already suggested for CSCs [53]. Interestingly, Stat3 is required for the maintenance of pluripotency in murine stem cells [54-7], and is necessary for self-renewal of murine neural stem cells $[58,59]$. Neural stem/progenitor cells has been identified in bioptic specimens from different tumors [60]. Moreover, neural stem cells and progenitors cells have been labeled by nestin [61] and CD133 [62, 63].
The data are in agreement with previously published studies showing that tumor cells can give rise to tumorassociated endothelial microvessels in human B-cell lymphomas, multiple myeloma, and malignant melanoma [64-67]. In this work we have demonstrated, for the first time, that FVIII positive tumor vessels are formed also by CD133, nestin and pStat 3 positive cells, suggesting that in PCNSL CSCs might contribute to the tumor vasculature. CSCs reside in a vascular niche named the CSC niche [68],

\section{pStat3\CD133}
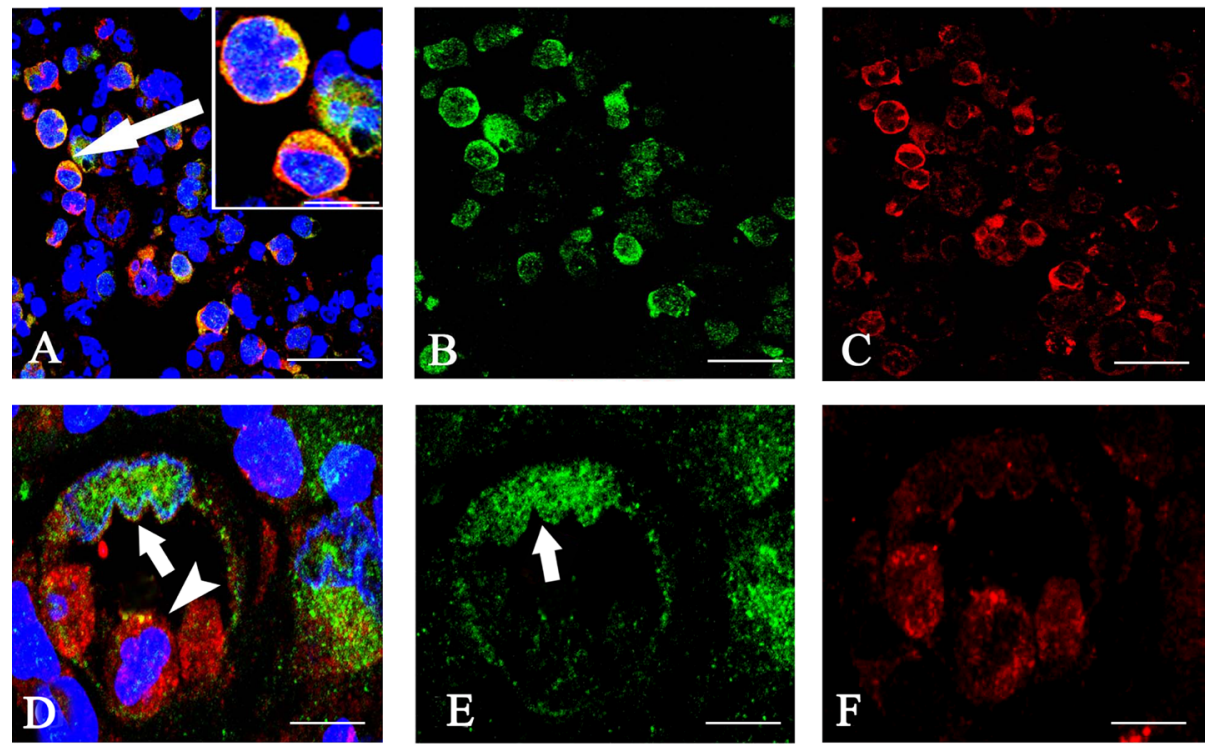

pStat $3 \backslash \mathrm{CD} 20$
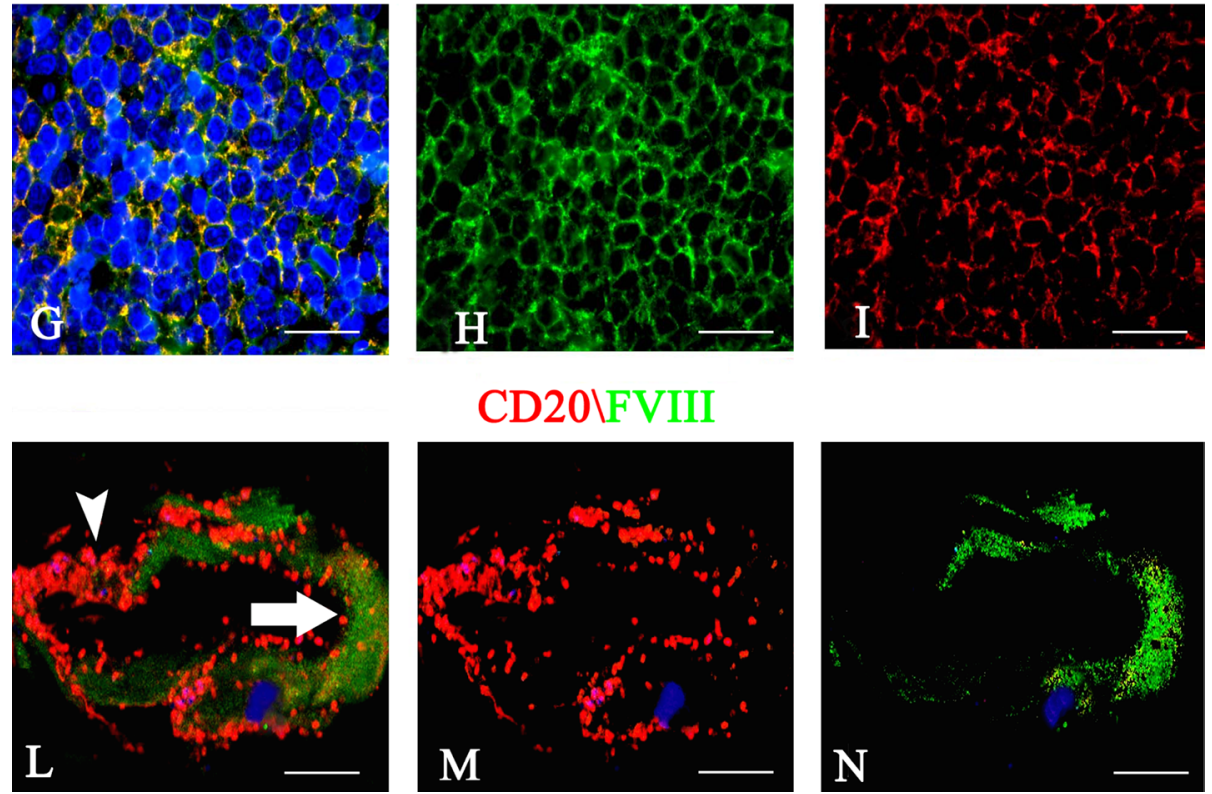

\section{CD20\FVIII}
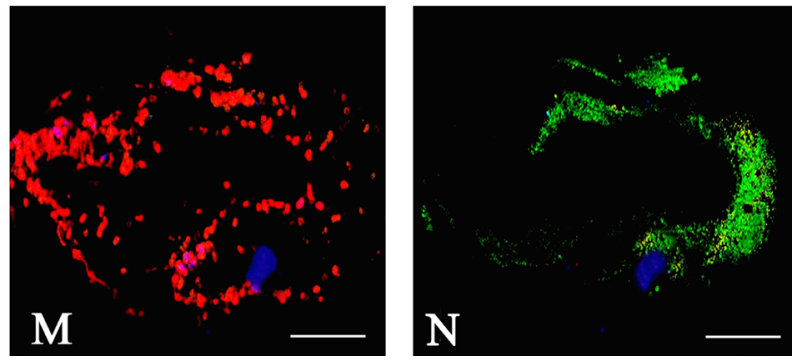

Figure 5: pStat3/CD133 (A-F), pStat3/CD20 (G-I) and CD20/FVIII (L-N) confocal dual immunofluorescence reaction. (A-C) Tumor cells labeled by anti-pStat3 (B) and anti-CD133 (C) antibodies with merged signal (A, arrow ). (D-F) Tumor vessel lined by green cells expressing pStat 3 with both nuclear (D, E arrow) and cytoplasmic fluorescence and by red cells expressing CD133 (D, F) with some points of colocalization (D, arrowhead). (G-I) PCNSL sections showing CD20 (I) red tumor cells coexpressing pStat3 (G, H) and tumor vessel expressing green FVIII endothelial (L, arrow) and red CD20 tumor signals (L, arrowhead). Scale Bar: A-C $22 \mu \mathrm{m}$; A insert $15 \mu \mathrm{m}, \mathrm{D}-\mathrm{F}$ $12 \mu \mathrm{m}$; G-I $20 \mu \mathrm{m} ; \mathrm{L}-\mathrm{N} 12 \mu \mathrm{m}$. 


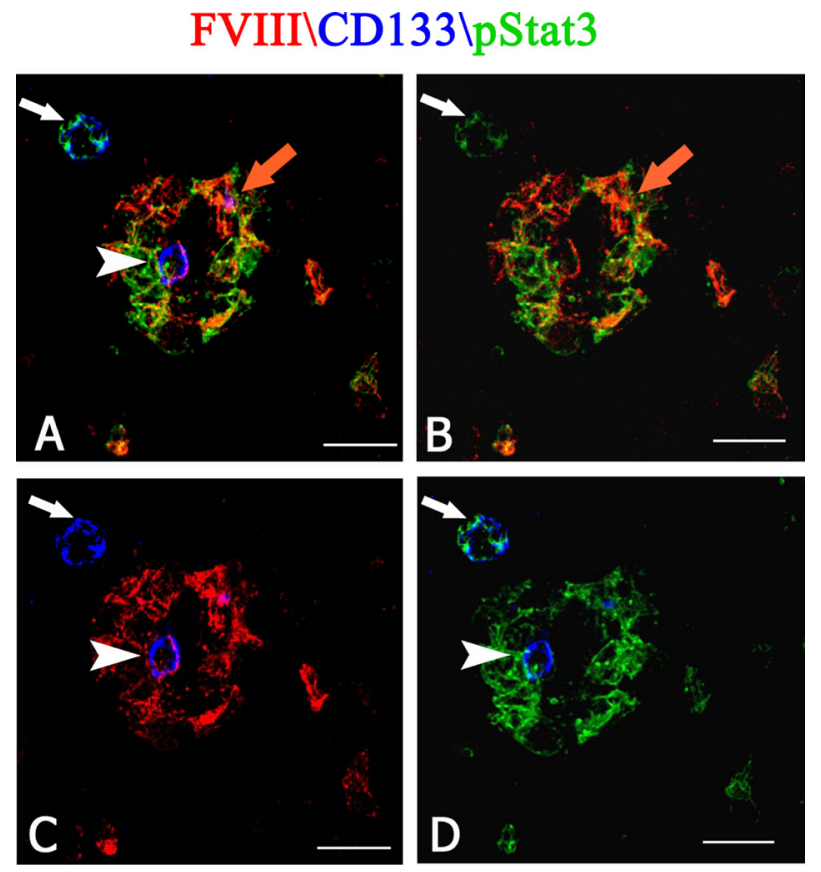

Figure 6: Multiple FVIII (red), CD133 (blue) and pStat3 (green) confocal immunofluoresce reaction. PCNSL tumor vessels lined by FVIII positive endothelial cells (A, B, C red signal) and expressing both pStat3 ( A, B, D green signal) and CD133 ( A, C, D blue signal). An orange signal of FVIII and pStat3 colocalization (A, B orange arrow) is present. Note a CD133 blue cells (A, C, $\mathrm{D}$, arrowhead) expressing FVIII red (A, C arrowhead) and pStat3 (D arrowhead) green fluorescence in the vessel and a CD133 blue cells (C, arrow) expressing pStat3 (A, B, D arrow) near the vessel. Scale bar : A-D $8 \mu \mathrm{m}$.

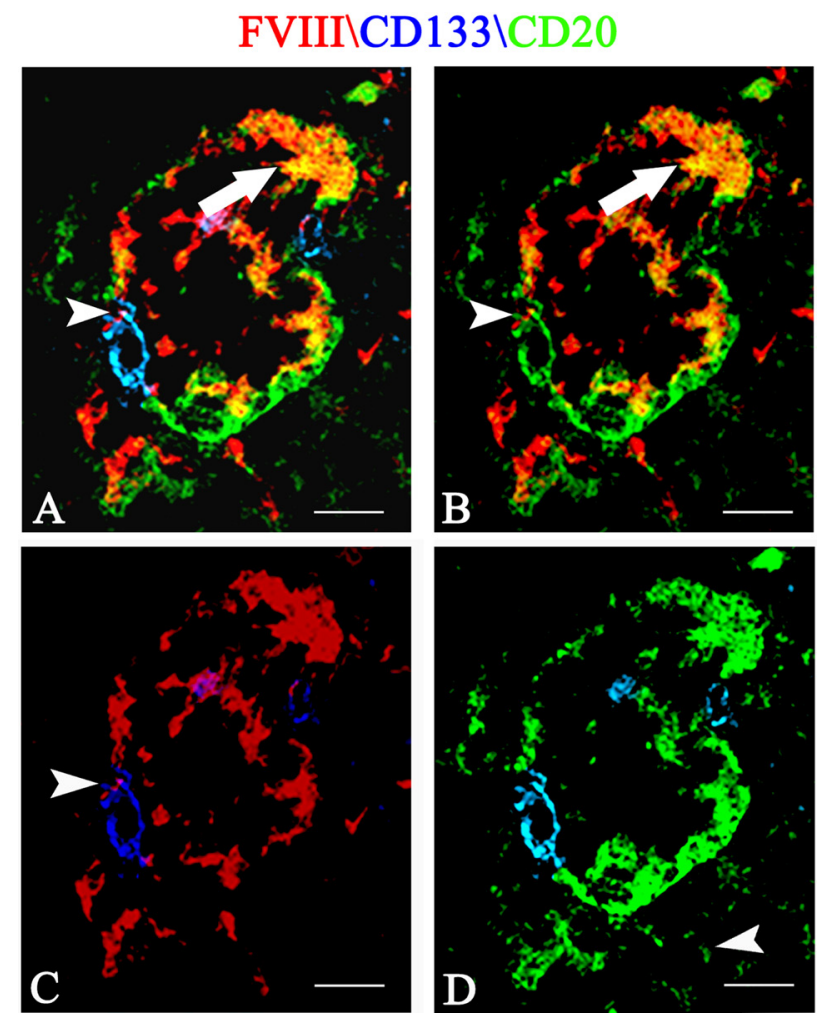

Figure 7: Multiple FVIII (red), CD133 (blue) and CD20 (green) confocal immunofluoresce reaction. Tumoral vessel co-expressing FVIII endothelial (A, B, C red signal ), CD20 tumoral (A, B, D, green signal) and CD133 CSCs markers (A, C, D blue signal). A FVIII $\backslash C D 20$ orange colocalization is recognizable (A, B arrow) and a CD133 labeled cells (A, C, D blue signal) express both red endothelial (A, B, C arrowhead) and green CD20 tumoral (B, D green) fluorescence. Scale bar: A-D $12 \mu \mathrm{m}$. 
and stimulate tumor angiogenesis. Tumor vasculature, in turn, supports CSC self-renewal and maintenance. CSCs produce high levels of VEGF [69], and recruit endothelial precursors for revascularization and tumor re-growth [70].

In addition, we further analyzed the tumor vasculature by combining FVIII and Stat3 dual immunofluorescence reactions and fluorescence in situ hybridization using the Stat3 locus specific probe (Chr:17q21.2) and the probe for chromosome 9q34.11.
We detected a fraction of $\mathrm{FVIII}^{+}$endothelial cell that coexpressed Stat3, bearing a tetraploid karyotype, while no amplification signal for Stat3 gene was detected. This polyploidy, a common feature of tumor cells, supports the notion that the tumor vascular endothelium in our PCNSL samples is of neoplastic origin. We also identified the same chromosomal aberration in $\mathrm{CD} 20^{+}$tumor cells. These findings confirm that in PCNSL, either the tumor cells can differentiate into endothelial cells.

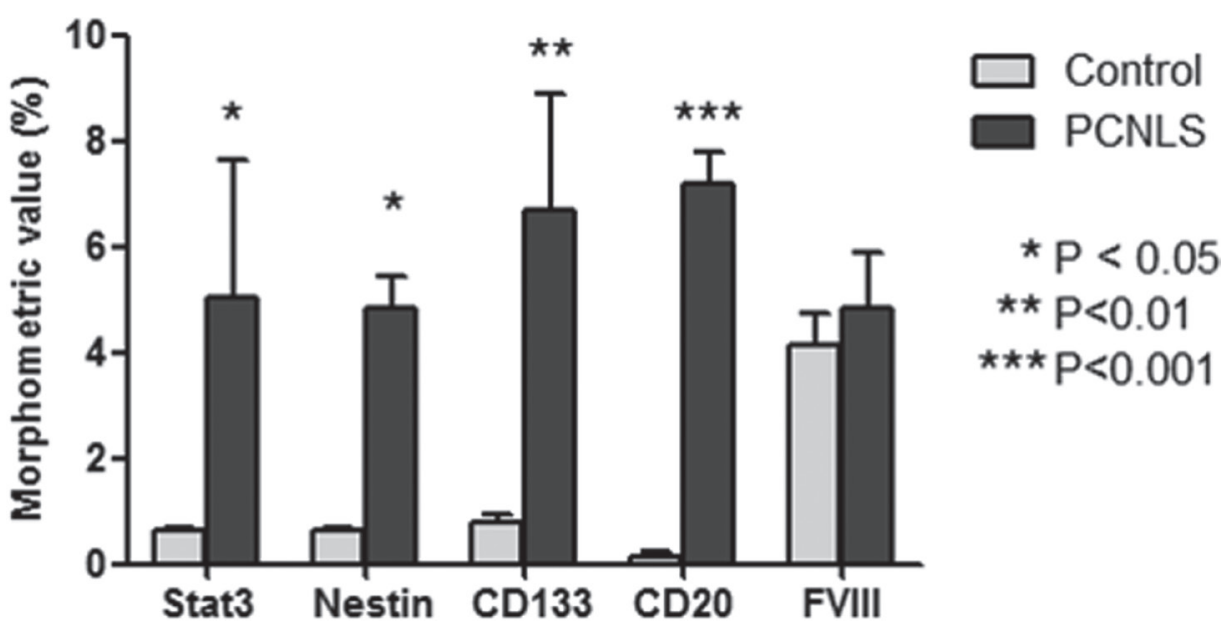

Figure 8: Morphometric analysis of Stat3, Nestin, CD133, CD20 and FVIII expression. Morphometric analysis shows a significant increased expression of Stat3, CD133, Nestin and CD20 protein in PCNSL compared with control brain.
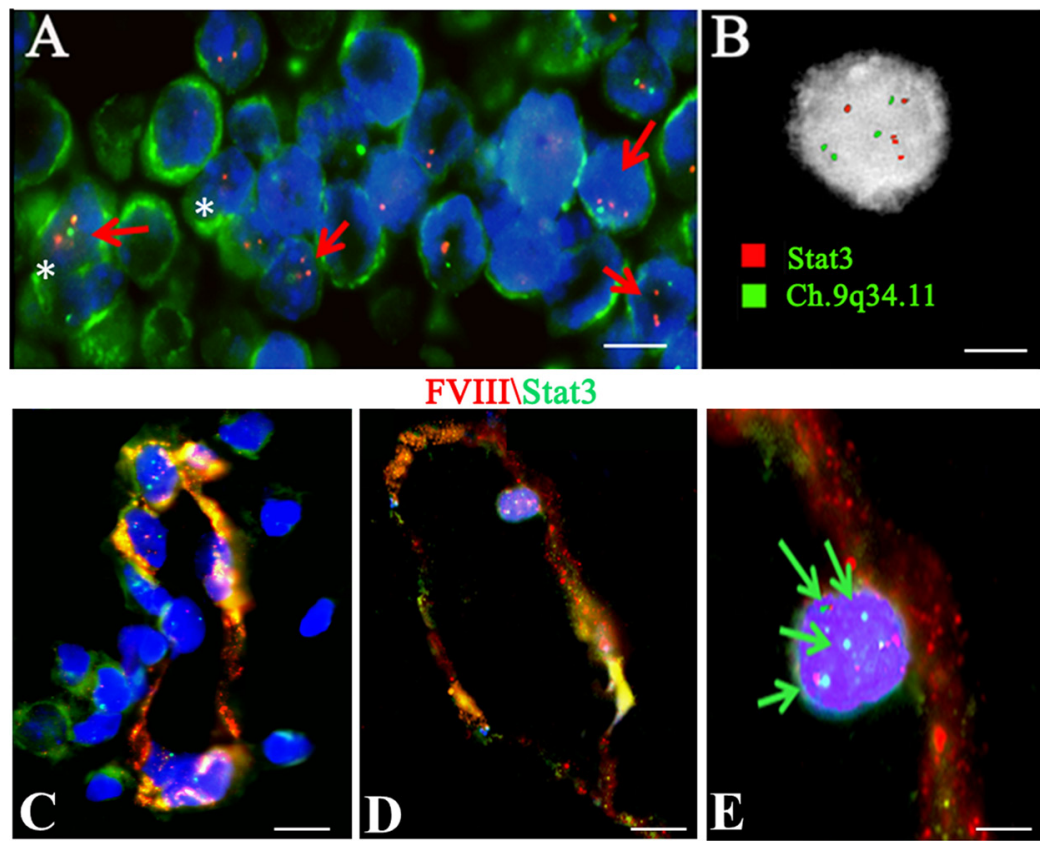

Figure 9: Tetraploid CD20 positive cells in PCNSL tissues and Tetraploid Stat3 positive cells in PCNSL vessels investigated by FICTION (A, C, D) and FISH (B) analysis. (A) Green CD20 tumor cells (A, white asterisk) show red and green aberrant fluorescent spots in the nuclei (A, red arrow). (B) Interphase Fish analysis showing four red (Ch: 17q21.31 Stat3) and four green (Ch: 9q34.11) fluorescent spots indicative of a tetraploid karyotype. (C-E) PCNSL vessel showing red FVIII and green Stat3 fluorescence with a tract showing an orange fluorescence signal. (E) FVIII/Stat3 labeled endothelial cells showing four green and red spot signals (green arrows). Scale bar: A $4 \mu \mathrm{m}$; B $2,5 \mu \mathrm{m} ; \mathrm{C}-\mathrm{D} 8 \mu \mathrm{m}$; E $3 \mu \mathrm{m}$. 
Genomic analysis of tumors demonstrates significant genetic intra- and inter-tumor heterogeneity [71]. Colorectal cancer endothelial cells overexpress specific transcripts as a result of qualitative differences in gene profiling as compared with endothelial cells of the normal colorectal mucosa [72]. Further studies in glioma [73] and in invasive breast carcinoma [74] demonstrated a distinct gene expression pattern related to tumor endothelial cells, which cells acquire genotype alterations, leading to altered anti-angiogenic targets and resistance [75], and the contiguity of tumor cells and endothelial cells may be responsible for the genotype alterations [76].

Overall, these data suggest that in PCNSL, putative endothelial cells lining the vascular wall are heterogeneous, and are formed by two cellular populations, expressing FVIII/ pStat3/CD133 (presumably originally they are vascular progenitor cells), as well as FVIII/CD20/CD133 (presumably originally they are tumor cells).

\section{MATERIALS AND METHODS}

\section{Patients and tissue samples}

The clinical and anatomical features of the patients investigated in this study are reported in Table 1. All patients were affected by histologically proven primary human diffuse large B-cell PCNSL. Surgical specimens were fixed in $4 \%$ formaldehyde, routinely processed and paraffin-embedded. Three samples of histologically normal brain, removed in the course of surgical exposure, were used as control. The study was approved by the local Ethics Committee at the University of Bari Medical School, and all the patients gave their informed consent in accordance with the declaration of Helsinki.

\section{Stat3, pStat3, CD133 and nestin immunohistochemistry}

Four $\mu \mathrm{m}$ thick histological sections collected on poly-L-lysine-coated slides (Sigma-Aldrich, St. Louis, MO, USA), were deparaffinized and stained with an automated immunostainer (Autostainer, Dako, Glostrup, Denmark) with a dextran polymer-based system method (EnVisionTM Flex ${ }^{+}$, Dako) using 3'-3'diaminobenzidine as chromogen. The sections were rehydrated in a xylenegraded alcohol scale and then rinsed for 10 minutes in $0.1 \mathrm{M}$ PBS. For Stat3, pStat3, CD133 and nestin immunodetection, sections were pretreated with sodium citrate pH 6.1 (Dako) solution for 30 minutes at $98^{\circ} \mathrm{C}$ in Dako PT Link for antigen retrieval, and then incubated with goat polyclonal anti-Stat3 (ab5073, Abcam discover more, Cambridge, UK), mouse monoclonal anti-pStat3 (sc56747, Santa Cruz Biotechnology, Santa Cruz, CA, USA), rabbit polyclonal anti-CD133 (ab19898, Abcam) and mouse monoclonal anti-nestin (sc23927, Santa
Cruz Biotechnology), diluted 1:50, 1:100, 1:200, 1:500 respectively. Thereafter, the sections were counterstained with Mayer hematoxylin and mounted in synthetic medium. Specific preimmune serum (Dako), replacing the primary antibodies, served as negative control.

\section{Morphometric analysis of Stat3 and pStat3 expression}

For each case, three slides stained for Stat3 and pStat3 expression were scanned using the wholeslide scanning platform Aperio Scanscope CS (Leica Biosystems, Nussloch, Germany). All the slides were scanned at the maximum available magnification $(40 \times)$ and stored as digital high resolution images on the workstation associated with the instrument. Digital slides were inspected with Aperio ImageScope v.11 software (Leica Biosystems, Nussloch, Germany) at $20 \times$ magnification and ten fields with an equal area were selected for the analysis at $40 \times$ magnification. Stat 3 and pStat 3 expression was assessed with the Positive Pixel Count algorithm embedded in the Aperio ImageScope software and reported as positivity percentage, defined as the number of positively stained pixels on the total pixels in the image. The statistical significance of differences between the mean values of the percent labeled areas between patients and control brain tissues was determined by the 2 way Anova test in GraphPad Prism 5.0 software (GraphPad software, La Jolla, CA, USA). Findings were considered significant at $P$ values $<0.05$.

\section{Real-time PCR}

Total RNA was extracted from FFPE blocks tissues of 20 patients and 3 normal control brain, using RecoverAll ${ }^{\mathrm{TM}}$ Total Nucleic Acid isolation kit (Ambion, Life Technologies, Inc., Austin, TX,USA) and then used to synthesize the first-strand c-DNA with the IScriptcDNA Synthesis kit (Bio-Rad Laboratories, Hercules, CA, USA), according to the manufacturer's instructions. For the detection of Stat3 expression, cDNA was amplified with the iTaq SYBR Green supermix using a ROX kit (Bio-Rad Laboratories). PCR amplification was performed using the Chromo4 real-time PCR Detection System (Bio-Rad Laboratories). Samples were normalized to human RPLPO (large ribosomal protein PO). Table 2 show the sequences of primers (Sigma-Aldrich) used for Stat 3 amplification.

\section{Dual and triple immunofluorescence-confocal laser scanning microscopy}

Twelve micrometer thick deparaffinized brain sections were incubated for 30 minutes in a blocking buffer [BB; phosphate-buffered saline (PBS), $\mathrm{pH} 7.4,1 \%$ bovine serum albumin, $2 \%$ fetal calf serum] and exposed to primary antibodies: (i) goat anti-Stat3 (ab5073, Abcam) 
Table 1: Clinical and anatomical features of 20 PCNSL patients ${ }^{\dagger}$

\begin{tabular}{|c|c|c|c|c|}
\hline Case & Sex & Age (years) & Tumor location & Ki 67* \\
\hline 1 & $\mathrm{M}$ & 40 & Parieto-frontal lobe & 80 \\
\hline 2 & $\mathrm{M}$ & 74 & Occipital lobe & 75 \\
\hline 3 & M & 82 & Occipital lobe & 40 \\
\hline 4 & M & 69 & Parietal lobe & 95 \\
\hline 5 & $\mathrm{M}$ & 72 & Parieto-temporal lobe & 60 \\
\hline 6 & M & 58 & Temporal lobe & 70 \\
\hline 7 & M & 72 & Basal ganglia & 90 \\
\hline 8 & $\mathrm{~F}$ & 65 & Cerebellar & 80 \\
\hline 9 & M & 72 & Frontal lobe and corpus callosum & 75 \\
\hline 10 & $\mathrm{~F}$ & 75 & Temporal lobe & 70 \\
\hline 11 & M & 66 & Frontal lobe & 85 \\
\hline 12 & $\mathrm{M}$ & 64 & Parieto-frontal lobe & 80 \\
\hline 13 & M & 73 & Parieto-frontal lobe & 80 \\
\hline 14 & $\mathrm{~F}$ & 38 & Multiple intra-cerebral & 65 \\
\hline 15 & $\mathrm{M}$ & 58 & Occipital lobe & 80 \\
\hline 16 & M & 72 & Parietal lobe & 45 \\
\hline 17 & $\mathrm{~F}$ & 64 & Parieto-occipital lobe & 80 \\
\hline 18 & $\mathrm{M}$ & 37 & Basal ganglia & 80 \\
\hline 19 & $\mathrm{~F}$ & 67 & Basal ganglia & 80 \\
\hline 20 & M & 44 & Cerebellar & 40 \\
\hline
\end{tabular}

${ }^{*} \mathrm{Ki}$-67 tumor proliferative index.

†All the patients have high degree of tumor and have been treated with a classic schema of chemotherapy, including methotrexate + Cytarabine (araC).

Table 2: Primer sequences for real-time PCR

\begin{tabular}{ll}
\hline Stat3/S & 5' GCTGGCTGACTGGAAGAG3' \\
Stat $3 /$ AS & 5' AGTTGAGATTCTGCTAATGACG3' \\
RPLPO/S & 5' CCTTCCCACTTGCTGAAAAGG 3' \\
RPLPO/AS & 5' ACAAAGGCAGATGGATCAGCC 3' \\
\hline
\end{tabular}

and rabbit anti-FVIII (A0082, Dako), diluted 1:100 and 1:50 in $\mathrm{BB}$, respectively, overnight at $4^{\circ} \mathrm{C}$; (ii) mouse anti-pStat3 (sc56747, Santa Cruz Biotechnology) and rabbit anti-CD133 (ab19898, Abcam), diluted 1:50 and 1:5 in $\mathrm{BB}$, respectively, overnight at $4^{\circ} \mathrm{C}$; (iii) mouse anti-CD133 (130-090-422, MACS Miltenyi Biotec, Bergisch Gladbach, Germany) and rabbit anti-FVIII (A0082, Dako), diluted 1:5 and 1:50 in BB, respectively, overnight at $4{ }^{\circ} \mathrm{C}$; (iv) rabbit anti-pStat3 (ab30647, Abcam) and mouse anti-CD20 (M0755, Dako), diluted 1:50 and 1:200 in $\mathrm{BB}$, respectively, overnight at $4^{\circ} \mathrm{C}$; (v) mouse anti-CD20 (M0755, Dako) and rabbit anti-FVIII (A0082, Dako), diluted 1:200 and 1:50 in BB, respectively, overnight at $4{ }^{\circ} \mathrm{C}$; (vi) mouse anti-nestin (sc23927, Santa Cruz Biotechnology) and rabbit anti-FVIII (A0082, Dako) diluted 1:50 in $\mathrm{BB}$ overnight at $4{ }^{\circ} \mathrm{C}$; (vii) rabbit anti-FVIII (A0082, Dako), mouse anti-CD133 (130-090-422, MACS Miltenyi Biotec) and mouse anti-pStat3 (sc56747, Santa Cruz Biotechnology), diluted 1:50, 1:100 and 1:100 in
$\mathrm{BB}$, respectively, overnight at $4^{\circ} \mathrm{C}$; (viii) rabbit anti-FVIII (A0082, Dako Corporation), mouse anti-CD133 (130090-422, MACS Miltenyi Biotec) and mouse anti-CD20 (M0755, Dako), diluted 1:50, 1:100 and 1:200 in BB, respectively, overnight at $4^{\circ} \mathrm{C}$ After washing in PBS the sections were incubated for 2 hours with the secondary antibodies: (i) Alexa Fluor 488 donkey anti-goat and Alexa Fluor 555 donkey anti-rabbit antibodies (Invitrogen, Carlsbad, CA, USA), diluted 1:300 in BB for Stat3/ FVIII dual localization; (ii) Alexa Fluor 488 goat antimouse and Alexa Fluor 555 goat anti-rabbit antibodies (Invitrogen) diluted 1:300 in BB for $\mathrm{pStat} 3 / \mathrm{CD} 133$; (iii) Alexa Fluor 488 goat anti-mouse and Alexa Fluor 555 goat anti-rabbit antibodies (Invitrogen) diluted 1:300 in BB for CD133/FVIII; (iv) Alexa Fluor 488 goat antirabbit and Alexa Fluor 555 goat anti-mouse antibodies (Invitrogen), diluted 1:300 in BB for pStat3/CD20 dual localization; (v) Alexa Fluor 555 goat anti-mouse and Alexa Fluor 488 goat anti-rabbit antibodies (Invitrogen), 
diluted 1:300 in BB for CD20/FVIII dual localization; (vi) Alexa Fluor 555 goat anti-mouse and Alexa Fluor 488 goat anti-rabbit antibodies (Invitrogen), diluted 1:300 in BB for nestin/FVIII dual localization; (vii) Alexa Fluor 555 goat anti-rabbit, Alexa Fluor 488 goat anti-mouse and Alexa Fluor 647 donkey anti-mouse antibodies (Invitrogen), diluted 1:300 in BB for FVIII/CD133/pStat3 triple localization; (viii) Alexa Fluor 555 goat anti-rabbit, Alexa Fluor 488 goat anti-mouse and Alexa Fluor 647 donkey anti-mouse antibodies (Invitrogen), diluted 1:300 in BB for FVIII/CD133/CD20 triple localization. All the samples were incubated for 20 minutes with $0.01 \%$ TOPRO-3 (Invitrogen) for nuclear staining and mounted in Vectashield (Vector Laboratories Inc., Burlingame, CA, USA). Negative controls, obtained by substituting primary antibodies with specific preimmune serum (Dako), showed no staining of the sections. The sections were examined under a Leica TCS SP5 (Leica,Wetzlar, Germany) confocal laser scanning microscope using $40 \times$ and 63 $\times$ objective lenses with either $1 \times$ or $2 \times$ zoom factors. A sequential scan procedure was applied during image acquisition of the two fluorophores. Confocal images were taken at $200 \mathrm{~nm}$ intervals through the z-axis of the section covering a total depth of $10 \mu \mathrm{m}$. Images from individual optical planes and multiple serial optical sections were analyzed, digitally recorded and stored as TIFF files using Adobe Photoshop software (Adobe Systems Inc., San Jose, CA, USA). Morphometric analysis was performed by two independent observers on ten randomly selected fields observed at $63 \times$ magnification by using $\mathrm{Cell}^{\wedge} \mathrm{F}$ as image analysis software (Olympus Italia,Rozzano,Italy).

\section{Morphometric analysis of nestin ${ }^{+} / \mathrm{FVIII}^{-}$, nestin $^{+} /$ $\mathrm{FVIII}^{+}, \mathrm{CD133}^{+} / \mathrm{FVIII}^{-}$and $\mathrm{CD}{ }^{+} 3^{+} / \mathrm{FVIII}^{+}$ vessels in PCNSL sections}

nestin $^{+} / \mathrm{FVIII}^{-}$, nestin $+\mathrm{FVIII}^{+}, \mathrm{CD} 133^{+} / \mathrm{FVIII}^{-}$and $\mathrm{CD} 33^{+} / \mathrm{FVIII}^{+}$vessels were evaluated from five optical fields randomly chosen for each PCNSL samples at $200 \times$ magnification. The images were acquired using the confocal fluorescence microscope (Leica) with an integrated camera. The software Cell ${ }^{\wedge} \mathrm{F}$ as image analysis (Olympus Italia,Rozzano,Italy) was applied for the vessel counting. The values were presented as percentage of positive vessels for each staining over the total vessels number. The data were expressed as mean value \pm SD.

\section{Morphometric analysis of pStat3 and CD133 cell expression}

The diameter of the pStat $3 \backslash \mathrm{CD} 133$ labeled and unlabeled cells were evaluated using Leica Confocal Multicolor Package (Leica Microsystems) on single optical planes of randomly chosen fields from ten sections per tumor and control samples with $63 \times$ oil lenses. The measure was made by optimized contrast and brightness enhancement functions and digital filters. The Graph Pad Prim 5.0 statistical package (GraphPad Software, San Diego, CA, USA) was used for the analysis and $P<0.05$ was considered as the limit for statistical significance. The data were expressed as mean value $\pm \mathrm{SD}$.

\section{FISH analysis}

FISH evaluation of paraffin sections was carried out with specific BAC clones. In detail, the Stat3 gene identification was performed using a pool of two BAC clones RP11-915H22 (17q21.2, chr17:42,310,278-42,457,908) and RP11-1151C17 (17q21.2, chr17:42,166,634-42,327,743) (UCSC, https://genome-euro.ucsc.edu/; Dec. 2013 release); as genome ploidy control, a contig of three BACs mapping on 9q34.11 was used (RP11-5J2, chr9:129,650,477129,813,833; RP11-409K20, chr9:129798948-129968911; RP11-138E2, chr9:129917913-130096675). PCNSL sample preparations were hybridized in situ with probes labeled directly with $\mathrm{Cy} 3$ and fluorescein by nick translation [24]. Briefly, 1000ng of each labeled probe was used for FISH cohybridization experiments; hybridization was performed at $37^{\circ} \mathrm{C}$ in $2 \mathrm{X}$ standard saline citrate, $50 \%$ (vol $\left./ \mathrm{vol}\right)$ formamide, $10 \%$ (wt/vol) dextran sulfate, 5mg COT1 DNA (Bethesda Research Laboratories, Gaithersburg, MD, USA), and $3 \mathrm{mg}$ sonicated salmon sperm DNA in a volume of 10 $\mathrm{ml}$. Post-hybridization washing was at $60^{\circ} \mathrm{C}(0.1 \mathrm{X}$ standard saline citrate). Interphase nuclei were identified by DAPI (4',6-diamidino-2-phenylindole staining). Digital images were obtained using a Leica DMRXA epifluorescence microscope equipped with a cooled CCD camera (Princeton Instruments, Boston, MA, USA). Cy3 (red; New England Nuclear, Boston, MA, USA), fluorescein (green; Fermentas Life Sciences, Milan, IT), and DAPI (blue) fluorescence signals, which were detected by using specific filters, were recorded separately as grayscale images. Pseudocoloring and merging of images were performed with Adobe Photoshop software (Adobe Systems Inc)

\section{Immunofluorescence and fluorescence in situ hybridization analysis (FICTION)}

Fluorescence immunophenotyping and interphase cytogenetics (FICTION), a technique combining immunofluorescence and FISH, was carried out on 4- $\mu \mathrm{m}$ thick paraffin sections of the PCNSL samples. For the identification of the chromosomal Stat3 signal in tumoral cells FISH assay was performed and then the sections were stained with either anti-CD20 antibody, a cytoplasmic tumoral cells marker, or with anti- FVIII, an endothelial cells marker, and anti-Stat3. In brief, deparaffinized and rehydrated slides were next incubated at $96^{\circ} \mathrm{C}$ in Tris/ EDTA acid buffer solution for 15 minutes, washed in sterile water and treated in $0.01 \mathrm{~N} \mathrm{HCL}$ solution at $37^{\circ} \mathrm{C}$ for 2 minutes. Enzymatic digestion was then performed by adding $200 \mu 10.4 \%$ pepsin (Sigma-Aldrich) solution 
Table 3: Primers for the PCR amplification of Stat3 (NM 139276.2)

\begin{tabular}{|c|c|c|}
\hline GENE & EXON & Primer sequence \\
\hline \multicolumn{3}{|l|}{ Stat3 } \\
\hline & 2 & F 5' GGACTTGTGGTGAACATATGC 3' \\
\hline & & R 5' CCTAACAATTTGGAGAGTCAC 3' \\
\hline & 3 & F 5' GTATGCGTCGGCTTCAGAGC 3' \\
\hline & & R 5' AACACTAACACCCGACTCTGC 3' \\
\hline & 4 & F 5' ACATCTCCATGGTCTGCTGC 3' \\
\hline & & R 5' CATTCCTCCCAGACCAGGG 3' \\
\hline & 5 & F 5' TAGTTCTGTGTTCACATGTGC 3' \\
\hline & & R TTAATGAAAGCTCCCTGCCC 3' \\
\hline & 6 & F 5' GGCTTCATTTGAATTCTCCTC 3' \\
\hline & & R 5' AACACAAACTCACTTTCTAGAG 3' \\
\hline & 7 & F 5' AGTATTCCCTCAGGTCAAGG 3' \\
\hline & & R 5' TGAAATCCCGCAAGTGAGCG 3' \\
\hline & 8 & F 5' TGGTTAGAGACAGTCTGAGG 3' \\
\hline & & R 5' TCAGAATTCAATCTAGCTTTCG 3' \\
\hline & 9 & F 5' CCATCTCACCTGTATACATTC 3' \\
\hline & & R 5' CTACCACGTGAGTCTTTAGG 3' \\
\hline & 10 & F 5' ACTTCTGGTCATGGCCGTG 3' \\
\hline & & R 5' CCTCAGTAAAATCTCTACTGG 3' \\
\hline & 11 & F 5' CTTGGCCTATTTACCTGTTGG 3' \\
\hline & & R 5' AATGATGTCTGTCAAAGTTCTC 3' \\
\hline & 12 & F 5' CAGTAAATAACAGGTGGTCAAAG 3' \\
\hline & & R 5' CAATCAACTATGTAGGTGACC 3' \\
\hline & 13 & F 5' GCTACTTGGTCACCTACATAG 3' \\
\hline & & R 5' AAAGGCAGGTGTCCTGTGAG 3' \\
\hline & 14 & F 5' ATTCAAACACTTGGTATGTGGG 3' \\
\hline & & R 5' GGTTGATGTTTCTAATTCTGGG 3' \\
\hline & 15 & F 5' TTACAGGCATGAGCCACCAC 3' \\
\hline & & R 5' GAAGTTTTTGTCCTGAGTCACC 3' \\
\hline & 16 & F 5'GATTTCCAAGGCTGTGAGAGC 3' \\
\hline & & R 5' ACCCCTAAGTCGCAAGAGATC 3' \\
\hline & 17 & F 5' GTACCTAGTATAGACAATGAGC 3' \\
\hline & & R 5' CTTTTCTGGGCGGGTGGG 3' \\
\hline & 18 & F 5' AATAACCTCTTGACCCCAAGC 3' \\
\hline & & R 5' AGCCGTGCAGGTGAGCATTC 3' \\
\hline & 19 & F 5' GCAGTAGACTTGGCTTTCCC 3' \\
\hline & & R 5' GGGACTTGGTTACATCTGTGC 3' \\
\hline & 20 & F 5' TGCCCTGTTAGCAATAACAAC 3' \\
\hline & & R 5' CAACTAGAAGCAGTGATGAGG 3' \\
\hline & 21 & F 5' TGAGATGACCTAGCTGTAGG 3' \\
\hline & & R 5' TCCAAGGATCCCAAAATTTCC 3' \\
\hline & 22 & F 5' CACAGTCAGTAAGAAAACTGG 3' \\
\hline & & R 5' ACCTTTGGCAGATTAACTCTC 3' \\
\hline & 23 & F 5'TTCCATTGTGTCTTGTCAACC 3' \\
\hline & & R 5' CTCGGTGTGTACATGTGAGAG 3' \\
\hline & 24 & F 5' CAGAGGGTGGACAATGAAC 3' \\
\hline & & R 5' TAGTAGTTTCAGATGATCTGGG 3' \\
\hline
\end{tabular}


and incubating at $37^{\circ} \mathrm{C}$ for 7 minutes. Thereafter, tissue samples were washed with sterile water, dehydrated in ethanol, and air dried. Hybridization was done with the Stat 3 probe and the centromeric probe of chromosome 9 as control. Probe and target were co-denatured at $75^{\circ} \mathrm{C}$ for 5 minutes, followed by overnight hybridization at $37^{\circ} \mathrm{C}$ on StatSpinThermoBrite (Abbott Molecular, Abbott Park, Illinois, USA). Post-hybridization washing was carried out at $72 \pm 1^{\circ} \mathrm{C}$ in $0.4 \mathrm{XSSC}$ for 2 minutes and in $2 \mathrm{XSSC} / 0.1 \%$ Tween at room temperature for 1 minute. Then the slides were counterstained and mounted with DAPI-Antifade (Cytocell, Tarrytown NY). After posthybridization washing, immunostaining was performed. The tissues were treated with normal goat serum at room temperature for 30 minutes and incubated overnight with mouse monoclonal anti-CD20, rabbit polyclonal antiFVIII (M0755 and A0082, Dako) and goat polyclonal antiStat3 (ab5073,Abcam) primary antibodies at $22^{\circ} \mathrm{C}$ then washed in PBS buffer and incubated at room temperature for 2 hours, with Alexa Fluor 488 goat anti-mouse, Alexa Fluor 555 donkey anti-rabbit and Alexa Fluor 488

donkey anti-goat (Invitrogen) antibodies, respectively, used as secondary reagent. Afterwards, the slides were washed, counterstained with DAPI (Invitrogen), and mounted in Vectashield (Vector Laboratories Inc.). Images were captured using an Olympus BX51 microscope fitted with an Olympus DP70 camera, equipped with filter sets for DAPI (nuclei counterstaining), FITC (cytoplasmic immunofluorescence signal and green nuclear FISH signal) and TRITC (cytoplasmic immunofluorescence signal and red nuclear FISH signal). Hybridization signals were counted in 200 morphologically intact nuclei for each sample.

\section{DNA extraction and sanger sequencing}

Genomic DNA was extracted from biopsy sections derived from PCNSL specimens using the QIAamp Mini Kit (Qiagen, Hilden, Germany), according to the manufacturer's instructions, and quantified on a BioSpectrometer Plus (Eppendorf, Hamburg, Germany). The entire coding regions of Stat3 (RefSeq NM_139276.2), including all splice junctions and adjacent intronic sequences, were amplified by standard PCR protocols using Taq DNA Polymerase (Thermo Scientific, USA) and the primer pairs listed in Table 3. Direct sequencing was performed using the BigDye Terminator v1.1 Cycle Sequencing Kit (Applied Biosystems) according to the manufacturer's instructions on an ABI 310 Genetic Analyzer (Applied Biosystems). The sequence analysis software Alamut ${ }^{\circledR}$ (Interactive Biosoftware) was used to interpret variants. Online databases including dbSNP (Database the Single Nucleotide Polymorphism Database), 1000 Genomes, ClinVar, EXAC (Exome Aggregation Consortium), COSMIC (Catalogue of Somatic Mutations in Cancer), ESP (Exome Sequencing
Project), as well as on line search engines (e.g. PubMed, LOVD), were used to search for previously described variants.

\section{Statistical analysis}

Data are reported as means \pm SEM. Student's t-test was used for two-group comparisons and Newman-Keuls multiple comparison post-test was used to compare all treatment groups following one-way ANOVA. The Graph Pad Prim 5.0 statistical package (GraphPad Software, San Diego, CA, USA) was used for the analysis and $P<0.05$ values were considered statistically significant.

\section{ACKNOWLEDGMENTS AND FUNDING}

This work was supported by European Union Seventh Framework Programme (FP7/2007-2013) under grant agreement n.278570 to DR

\section{CONFLICTS OF INTEREST}

All authors declare no conflicts of interest.

\section{REFERENCES}

1. Yamanaka R, Morii K, Shinbo Y, Homma J, Sano M, Tsuchiya N, Yajima N, Tamura T, Hondoh H, Takahashi H, Kakuma T, Tanaka R. Results of treatment of 112 cases of primary CNS lymphoma. Jpn J Clin Oncol. 2008; 38:373-80.

2. Schuurmans M, Bromberg JE, Doorduijn J, Poortmans P, Taphoorn MJ, Seute T, Enting R, van Imhoff G, van Norden Y, van den Bent MJ. Primary central nervous system lymphoma in the elderly: a multicentre retrospective analysis. Br J Haematol. 2010; 151:179-84.

3. Hochberg FH, Baehring JM, Hochberg EP. Primary CNS lymphoma. Nat Clin Pract Neurol. 2007; 3:24-35.

4. Paulus W. Classification, pathogenesis and molecular pathology of primary CNS lymphomas. J Neurooncol. 1999; 43:203-08.

5. Ribatti D, Nico B, Ranieri G, Specchia G, Vacca A. The role of angiogenesis in human non-Hodgkin lymphomas. Neoplasia. 2013; 15:231-38.

6. Takeuchi H, Matsuda K, Kitai R, Sato K, Kubota T. Angiogenesis in primary central nervous system lymphoma (PCNSL). J Neurooncol. 2007; 84:141-45.

7. Nico B, Annese T, Tamma R, Longo V, Ruggieri S, Senetta R, Cassoni P, Specchia G, Vacca A, Ribatti D. Aquaporin-4 expression in primary human central nervous system lymphomas correlates with tumour cell proliferation and phenotypic heterogeneity of the vessel wall. Eur J Cancer. 2012; 48:772-81.

8. Beier D, Hau P, Proescholdt M, Lohmeier A, Wischhusen J, Oefner PJ, Aigner L, Brawanski A, Bogdahn U, Beier CP. CD133(+) and CD133(-) glioblastoma-derived cancer stem 
cells show differential growth characteristics and molecular profiles. Cancer Res. 2007; 67:4010-15.

9. Bao S, Wu Q, Sathornsumetee S, Hao Y, Li Z, Hjelmeland AB, Shi Q, McLendon RE, Bigner DD, Rich JN. Stem cell-like glioma cells promote tumor angiogenesis through vascular endothelial growth factor. Cancer Res. 2006; 66:7843-48.

10. Stupp R, Hegi ME. Targeting brain-tumor stem cells. Nat Biotechnol. 2007; 25:193-94.

11. Brantley EC, Benveniste EN. Signal transducer and activator of transcription-3: a molecular hub for signaling pathways in gliomas. Mol Cancer Res. 2008; 6:675-84.

12. Bowman T, Garcia R, Turkson J, Jove R. STATs in oncogenesis. Oncogene. 2000; 19:2474-88.

13. Kim JE, Patel M, Ruzevick J, Jackson CM, Lim M. STAT3 Activation in Glioblastoma: Biochemical and Therapeutic Implications. Cancers (Basel). 2014; 6:376-95.

14. Yoshimura A. Signal transduction of inflammatory cytokines and tumor development. Cancer Sci. 2006; 97:439-47.

15. Yu H, Kortylewski M, Pardoll D. Crosstalk between cancer and immune cells: role of STAT3 in the tumour microenvironment. Nat Rev Immunol. 2007; 7:41-51.

16. Stewart DA, Bahlis N, Mansoor A. pY-STAT3 and p53 expression predict outcome for poor prognosis diffuse large B-cell lymphoma treated with high dose chemotherapy and autologous stem cell transplantation. Leuk Lymphoma. 2009; 50:1276-82.

17. Ding BB, Yu JJ, Yu RY, Mendez LM, Shaknovich R, Zhang Y, Cattoretti G, Ye BH. Constitutively activated STAT3 promotes cell proliferation and survival in the activated B-cell subtype of diffuse large B-cell lymphomas. Blood. 2008; 111:1515-23.

18. Jost PJ, Ruland J. Aberrant NF-kappaB signaling in lymphoma: mechanisms, consequences, and therapeutic implications. Blood. 2007; 109:2700-07.

19. Lam LT, Wright G, Davis RE, Lenz G, Farinha P, Dang L, Chan JW, Rosenwald A, Gascoyne RD, Staudt LM. Cooperative signaling through the signal transducer and activator of transcription 3 and nuclear factor-\{kappa $\}$ B pathways in subtypes of diffuse large B-cell lymphoma. Blood. 2008; 111:3701-13.

20. Vajpayee N, Hussain J, Tolocica I, Hutchison RE, Gajra A. Expression of signal transducer and activator of transcription 3 (STAT3) in primary central nervous system diffuse large B-cell lymphoma: a retrospective analysis of 17 cases. J Neurooncol. 2010; 100:249-53.

21. Komohara Y, Horlad H, Ohnishi K, Ohta K, Makino K, Hondo H, Yamanaka R, Kajiwara K, Saito T, Kuratsu J, Takeya M. M2 macrophage/microglial cells induce activation of Stat3 in primary central nervous system lymphoma. J Clin Exp Hematop. 2011; 51:93-99.

22. Bai B, Horlad H, Saito Y, Ohnishi K, Fujiwara Y, Takeya M, Komohara Y. Role of Stat3 activation in cell-cell interaction between B-cell lymphoma and macrophages: the in vitro study. J Clin Exp Hematop. 2013; 53:127-33.
23. Ashizawa T, Miyata H, Iizuka A, Komiyama M, Oshita C, Kume A, Nogami M, Yagoto M, Ito I, Oishi T, Watanabe R, Mitsuya K, Matsuno K, et al. Effect of the STAT3 inhibitor STX-0119 on the proliferation of cancer stem-like cells derived from recurrent glioblastoma. Int J Oncol. 2013; 43:219-27.

24. Storlazzi CT, Albano F, Locunsolo C, Lonoce A, Funes S, Guastadisegni MC, Cimarosto L, Impera L, D'Addabbo P, Panagopoulos I, Specchia G, Rocchi M. t(3;12)(q26;q14) in polycythemia vera is associated with upregulation of the HMGA2 gene. Leukemia. 2006; 20:2190-92.

25. Kerbel RS. Tumor angiogenesis: past, present and the near future. Carcinogenesis. 2000; 21:505-15.

26. Bergers G, Benjamin LE. Tumorigenesis and the angiogenic switch. Nat Rev Cancer. 2003; 3:401-10.

27. Jain RK, di Tomaso E, Duda DG, Loeffler JS, Sorensen AG, Batchelor TT. Angiogenesis in brain tumours. Nat Rev Neurosci. 2007; 8:610-22.

28. Doucette TA, Kong LY, Yang Y, Ferguson SD, Yang J, Wei J, Qiao W, Fuller GN, Bhat KP, Aldape K, Priebe W, Bögler O, Heimberger AB, Rao G. Signal transducer and activator of transcription 3 promotes angiogenesis and drives malignant progression in glioma. Neuro-oncol. 2012; 14:1136-45.

29. Cheng F, Wang HW, Cuenca A, Huang M, Ghansah T, Brayer J, Kerr WG, Takeda K, Akira S, Schoenberger SP, Yu H, Jove R, Sotomayor EM. A critical role for Stat3 signaling in immune tolerance. Immunity. 2003; 19:425-36.

30. See AP, Han JE, Phallen J, Binder Z, Gallia G, Pan F, Jinasena D, Jackson C, Belcaid Z, Jeong SJ, Gottschalk $\mathrm{C}$, Zeng J, Ruzevick J, et al. The role of STAT3 activation in modulating the immune microenvironment of GBM. J Neurooncol. 2012; 110:359-68.

31. Fuh B, Sobo M, Cen L, Josiah D, Hutzen B, Cisek K, Bhasin D, Regan N, Lin L, Chan C, Caldas H, DeAngelis $\mathrm{S}$, Li C, et al. LLL-3 inhibits STAT3 activity, suppresses glioblastoma cell growth and prolongs survival in a mouse glioblastoma model. Br J Cancer. 2009; 100:106-12.

32. Gao L, Li F, Dong B, Zhang J, Rao Y, Cong Y, Mao B, Chen X. Inhibition of STAT3 and ErbB2 suppresses tumor growth, enhances radiosensitivity, and induces mitochondria-dependent apoptosis in glioma cells. Int $\mathrm{J}$ Radiat Oncol Biol Phys. 2010; 77:1223-31.

33. Li GH, Wei H, Lv SQ, Ji H, Wang DL. Knockdown of STAT3 expression by RNAi suppresses growth and induces apoptosis and differentiation in glioblastoma stem cells. Int J Oncol. 2010; 37:103-10.

34. Lui VW, Boehm AL, Koppikar P, Leeman RJ, Johnson D, Ogagan M, Childs E, Freilino M, Grandis JR. Antiproliferative mechanisms of a transcription factor decoy targeting signal transducer and activator of transcription (STAT) 3: the role of STAT1. Mol Pharmacol. 2007; 71:1435-43.

35. Nam S, Buettner R, Turkson J, Kim D, Cheng JQ, Muehlbeyer S, Hippe F, Vatter S, Merz KH, Eisenbrand 
G, Jove R. Indirubin derivatives inhibit Stat3 signaling and induce apoptosis in human cancer cells. Proc Natl Acad Sci USA. 2005; 102:5998-6003.

36. Spiekermann K, Biethahn S, Wilde S, Hiddemann W, Alves F. Constitutive activation of STAT transcription factors in acute myelogenous leukemia. Eur J Haematol. 2001; 67:63-71.

37. Iwamaru A, Szymanski S, Iwado E, Aoki H, Yokoyama T, Fokt I, Hess K, Conrad C, Madden T, Sawaya R, Kondo S, Priebe W, Kondo Y. A novel inhibitor of the STAT3 pathway induces apoptosis in malignant glioma cells both in vitro and in vivo. Oncogene. 2007; 26:2435-44.

38. Lin L, Hutzen B, Zuo M, Ball S, Deangelis S, Foust E, Pandit B, Ihnat MA, Shenoy SS, Kulp S, Li PK, Li C, Fuchs J, Lin J. Novel STAT3 phosphorylation inhibitors exhibit potent growth-suppressive activity in pancreatic and breast cancer cells. Cancer Res. 2010; 70:2445-54.

39. Sun J, Blaskovich MA, Jove R, Livingston SK, Coppola D, Sebti SM. Cucurbitacin Q: a selective STAT3 activation inhibitor with potent antitumor activity. Oncogene. 2005; 24:3236-45.

40. Duan Z, Bradner JE, Greenberg E, Levine R, Foster R, Mahoney J, Seiden MV. SD-1029 inhibits signal transducer and activator of transcription 3 nuclear translocation. Clin Cancer Res. 2006; 12:6844-52.

41. Blaskovich MA, Sun J, Cantor A, Turkson J, Jove R, Sebti SM. Discovery of JSI-124 (cucurbitacin I), a selective Janus kinase/signal transducer and activator of transcription 3 signaling pathway inhibitor with potent antitumor activity against human and murine cancer cells in mice. Cancer Res. 2003; 63:1270-79.

42. Hedvat M, Huszar D, Herrmann A, Gozgit JM, Schroeder A, Sheehy A, Buettner R, Proia D, Kowolik CM, Xin $\mathrm{H}$, Armstrong B, Bebernitz G, Weng S, et al. The JAK2 inhibitor AZD1480 potently blocks Stat3 signaling and oncogenesis in solid tumors. Cancer Cell. 2009; 16:487-97.

43. Berstein LM, Boyarkina MP, Teslenko SY. Familial diabetes is associated with reduced risk of cancer in diabetic patients: a possible role for metformin. Med Oncol. 2012; 29:1308-13.

44. Evans JM, Donnelly LA, Emslie-Smith AM, Alessi DR, Morris AD. Metformin and reduced risk of cancer in diabetic patients. BMJ. 2005; 330:1304-05.

45. Brantley EC, Nabors LB, Gillespie GY, Choi YH, Palmer CA, Harrison K, Roarty K, Benveniste EN. Loss of protein inhibitors of activated STAT-3 expression in glioblastoma multiforme tumors: implications for STAT-3 activation and gene expression. Clin Cancer Res. 2008; 14:4694-704.

46. Mandal T, Bhowmik A, Chatterjee A, Chatterjee U, Chatterjee S, Ghosh MK. Reduced phosphorylation of Stat3 at Ser-727 mediated by casein kinase 2 - protein phosphatase 2A enhances Stat3 Tyr-705 induced tumorigenic potential of glioma cells. Cell Signal. 2014; 26:1725-34.

47. Yu H, Pardoll D, Jove R. STATs in cancer inflammation and immunity: a leading role for STAT3. Nat Rev Cancer. 2009; 9:798-809.
48. Sullivan NJ, Sasser AK, Axel AE, Vesuna F, Raman V, Ramirez N, Oberyszyn TM, Hall BM. Interleukin-6 induces an epithelial-mesenchymal transition phenotype in human breast cancer cells. Oncogene. 2009; 28:2940-47.

49. Colomiere M, Ward AC, Riley C, Trenerry MK, CameronSmith D, Findlay J, Ackland L, Ahmed N. Cross talk of signals between EGFR and IL-6R through JAK2/STAT3 mediate epithelial-mesenchymal transition in ovarian carcinomas. Br J Cancer. 2009; 100:134-44.

50. Mizowaki T, Sasayama T, Tanaka K, Mizukawa K, Takata K, Nakamizo S, Tanaka H, Nagashima H, Nishihara M, Hirose T, Itoh T, Kohmura E. STAT3 activation is associated with cerebrospinal fluid interleukin-10 (IL-10) in primary central nervous system diffuse large B cell lymphoma. J Neurooncol. 2015; 124:165-74.

51. Bromberg J, Darnell JE Jr. The role of STATs in transcriptional control and their impact on cellular function. Oncogene. 2000; 19:2468-73.

52. Darnell JE Jr. STATs and gene regulation. Science. 1997; 277:1630-35.

53. Seftor RE, Hess AR, Seftor EA, Kirschmann DA, Hardy KM, Margaryan NV, Hendrix MJ. Tumor cell vasculogenic mimicry: from controversy to therapeutic promise. Am $\mathrm{J}$ Pathol. 2012; 181:1115-25.

54. Niwa H, Burdon T, Chambers I, Smith A. Self-renewal of pluripotent embryonic stem cells is mediated via activation of STAT3. Genes Dev. 1998; 12:2048-60.

55. Boeuf H, Hauss C, Graeve FD, Baran N, Kedinger C. Leukemia inhibitory factor-dependent transcriptional activation in embryonic stem cells. J Cell Biol. 1997; 138:1207-17.

56. Raz R, Lee CK, Cannizzaro LA, d'Eustachio P, Levy DE. Essential role of STAT3 for embryonic stem cell pluripotency. Proc Natl Acad Sci USA. 1999; 96:2846-51.

57. Cheng GZ, Zhang WZ, Sun M, Wang Q, Coppola D, Mansour M, Xu LM, Costanzo C, Cheng JQ, Wang LH. Twist is transcriptionally induced by activation of STAT3 and mediates STAT3 oncogenic function. J Biol Chem. 2008; 283:14665-73.

58. Gu F, Hata R, Ma YJ, Tanaka J, Mitsuda N, Kumon Y, Hanakawa Y, Hashimoto K, Nakajima K, Sakanaka M. Suppression of Stat3 promotes neurogenesis in cultured neural stem cells. J Neurosci Res. 2005; 81:163-71.

59. Yoshimatsu T, Kawaguchi D, Oishi K, Takeda K, Akira S, Masuyama N, Gotoh Y. Non-cell-autonomous action of STAT3 in maintenance of neural precursor cells in the mouse neocortex. Development. 2006; 133:2553-63.

60. Campbell JG, Miller DC, Cundiff DD, Feng Q, Litofsky NS. Neural stem/progenitor cells react to non-glial cns neoplasms. Springerplus. 2015; 4:53.

61. Sugawara K, Kurihara H, Negishi M, Saito N, Nakazato Y, Sasaki T, Takeuchi T. Nestin as a marker for proliferative endothelium in gliomas. Lab Invest. 2002; 82:345-51.

62. Yi L, Zhou ZH, Ping YF, Chen JH, Yao XH, Feng H, Lu JY, Wang JM, Bian XW. Isolation and characterization of stem 
cell-like precursor cells from primary human anaplastic oligoastrocytoma. Mod Pathol. 2007; 20:1061-68.

63. Li Z. CD133: a stem cell biomarker and beyond. Exp Hematol Oncol. 2013; 2:17.

64. Streubel B, Chott A, Huber D, Exner M, Jäger U, Wagner $\mathrm{O}$, Schwarzinger I. Lymphoma-specific genetic aberrations in microvascular endothelial cells in B-cell lymphomas. N Engl J Med. 2004; 351:250-59.

65. Gunsilius E, Duba HC, Petzer AL, Kähler CM, Grünewald K, Stockhammer G, Gabl C, Dirnhofer S, Clausen J, Gastl G. Evidence from a leukaemia model for maintenance of vascular endothelium by bone-marrow-derived endothelial cells. Lancet. 2000; 355:1688-91.

66. Rigolin GM, Fraulini C, Ciccone M, Mauro E, Bugli AM, De Angeli C, Negrini M, Cuneo A, Castoldi G. Neoplastic circulating endothelial cells in multiple myeloma with 13q14 deletion. Blood. 2006; 107:2531-35.

67. Fonsato V, Buttiglieri S, Deregibus MC, Puntorieri V, Bussolati B, Camussi G. Expression of Pax2 in human renal tumor-derived endothelial cells sustains apoptosis resistance and angiogenesis. Am J Pathol. 2006; 168:706-13.

68. Calabrese C, Poppleton H, Kocak M, Hogg TL, Fuller C, Hamner B, Oh EY, Gaber MW, Finklestein D, Allen M, Frank A, Bayazitov IT, Zakharenko SS, et al. A perivascular niche for brain tumor stem cells. Cancer Cell. 2007; 11:69-82.

69. Alvero $\mathrm{AB}, \mathrm{Fu} \mathrm{HH}$, Holmberg J, Visintin I, Mor L, Marquina CC, Oidtman J, Silasi DA, Mor G. Stemlike ovarian cancer cells can serve as tumor vascular progenitors. Stem Cells. 2009; 27:2405-13.
70. Folkins C, Shaked Y, Man S, Tang T, Lee CR, Zhu Z, Hoffman RM, Kerbel RS. Glioma tumor stem-like cells promote tumor angiogenesis and vasculogenesis via vascular endothelial growth factor and stromal-derived factor 1. Cancer Res. 2009; 69:7243-51.

71. Yap TA, Gerlinger M, Futreal PA, Pusztai L, Swanton C. Intratumor heterogeneity: seeing the wood for the trees. Sci Transl Med. 2012; 4:127ps10.

72. St Croix B, Rago C, Velculescu V, Traverso G, Romans KE, Montgomery E, Lal A, Riggins GJ, Lengauer C, Vogelstein B, Kinzler KW. Genes expressed in human tumor endothelium. Science. 2000; 289:1197-202.

73. Madden SL, Cook BP, Nacht M, Weber WD, Callahan MR, Jiang Y, Dufault MR, Zhang X, Zhang W, Walter-Yohrling J, Rouleau C, Akmaev VR, Wang CJ, et al. Vascular gene expression in nonneoplastic and malignant brain. Am J Pathol. 2004; 165:601-08.

74. Parker BS, Argani P, Cook BP, Liangfeng H, Chartrand SD, Zhang M, Saha S, Bardelli A, Jiang Y, St Martin TB, Nacht $\mathrm{M}$, Teicher BA, Klinger KW, et al. Alterations in vascular gene expression in invasive breast carcinoma. Cancer Res. 2004; 64:7857-66.

75. Hida K, Hida Y, Amin DN, Flint AF, Panigrahy D, Morton CC, Klagsbrun M. Tumor-associated endothelial cells with cytogenetic abnormalities. Cancer Res. 2004; 64:8249-55.

76. Hida K, Klagsbrun M. A new perspective on tumor endothelial cells: unexpected chromosome and centrosome abnormalities. Cancer Res. 2005; 65:2507-10. 